\title{
LHCGR wt Allele
}

National Cancer Institute

\section{Source}

National Cancer Institute. LHCGR wt Allele. NCI Thesaurus. Code C158718.

Human LHCGR wild-type allele is located in the vicinity of 2p16.3 and is approximately 69 $\mathrm{kb}$ in length. This allele, which encodes lutropin-choriogonadotropic hormone receptor protein, is involved in binding luteinizing hormone and choriogonadotropin and G proteincoupled receptor signaling. Mutation of the gene is associated with luteinizing hormone resistance in females, precocious puberty in males, somatic Leydig cell adenoma with precocious puberty and Leydig cell hypoplasia with either pseudohermaphroditism or hypergonadotropic hypogonadism. 